\title{
Controlled release fertilizer encapsulated by a к-carrageenan hydrogel
}

\author{
Gladys Rozo ${ }^{\text {* }}$ (D), Laura Bohorques² and Johanna Santamaría ${ }^{3}$ \\ 'Departmento de Ciencias Básicas y Modelado, Universidad Jorge Tadeo Lozano, Bogotá, DC, Colombia \\ ${ }^{2}$ Proyecto Curricular de Licenciatura en Química, Universidad Francisco José de Caldas, Bogotá, \\ Colombia \\ ${ }^{3}$ Departmento de Ciencias Biológicas y Ambientales, University Jorge Tadeo Lozano, Bogotá, Colombia \\ *gladys.rozo@utadeo.edu.co
}

\begin{abstract}
The release kinetics of nitrogen and phosphorous of a granulated fertilizer, encapsulated in a $\kappa$-carrageenan-based hydrogel $(\mathrm{CBH})$, was evaluated in order to determine its release mechanism given the potential this hydrogel has as coating material for controlled release fertilizers (CFRs). The effect of $\mathrm{pH}$ on the release properties was also investigated. The relationship between the $\mathrm{NH}_{4}^{+}, \mathrm{NO}_{3}^{-}$, and $\mathrm{PO}_{4}^{3-}$ release of encapsulated fertilizers and time was determined by short- and long-term laboratory incubations. The mechanism of the release of nutrient ions was determined by comparing the release data with the zero-order, first-order, Higuchi, Hixon-Crowell and Korsmeyer-Peppas kinetic models. The findings showed that the Korsmeyer-Peppas model could be used to describe the release characteristics of the nutrients in the encapsulated fertilizers and that non-Fickian diffusion is the main release mechanism. The experimental hydrogel showed a high water retention capacity able to absorb 300 times its weight water.
\end{abstract}

Keywords: carrageenan, controlled release fertilizers, hydropolymers, release behavior.

How to cite: Rozo, G., Bohorques, L., \& Santamaría, J. (2019). Controlled release fertilizer encapsulated by a א-carrageenan hydrogel . Polimeros: Ciência e Tecnologiam 29(3), e2019033. https://doi.org/10.1590/0104-1428.02719

\section{Introduction}

The use of fertilizers since the end of the World War II significantly increased the production per unit area, allowing the agricultural industry to meet the demand for food of the increasing human populations ${ }^{[1-3]}$. Despite the positive impact these inputs have on productivity, their use is inefficient. Less than $50 \%$ of the nitrogen $(\mathrm{N})$ and phosphorus $(\mathrm{P})$ in the fertilizers is taken up by the plants ${ }^{[4,5]}$. The non-assimilated nutrients are lost by leaching or by volatilization into the atmosphere ${ }^{[4,6,7]}$, causing serious environmental problems and economic losses ${ }^{[8-11]}$.

In coated controlled release fertilizers (CRFs), the mechanism and the factors influencing the speed and duration of the nutrient release are known and controllable, and they are currently being used as a strategy to decrease the rate at which nutrients are released from the fertilizer to the soil solution, allowing synchronization between the onset of nutrient uptake by the crop and the availability of nutrients ${ }^{[12]}$. Another important aspect of CRFs is the rate of reduction in nutrient removal from soil by rain or irrigation water ${ }^{[13]}$, which can help mitigate the eutrophication and greenhouse gases flow to the atmosphere as a result of reduction of the $\mathrm{N}$ and $\mathrm{P}$ output from the productive systems. Among the materials being used commercially as fertilizer coatings are minerals and synthetic polymers ${ }^{[14-16]}$. Although these materials have proven to be useful for increasing nutrient use efficiency and for decreasing nutrient losses

from the agricultural production system ${ }^{[17-19]}$, they may be toxic and / or nonbiodegradable; additionally, they raise the fertilizer price ${ }^{[12,14]}$, which prevents a more frequent use by producers. For this reason, the search has begun for a low cost, nontoxic, biodegradable material within the different organic polymers of natural origin that can be used as a coating for fertilizer grains ${ }^{[16,19-21]}$.

In the search for alternative coating materials, the use of Carrageenan, a family of sulfated polysaccharides found in the wall of red algae of the Rhodophyceae class, has begun to be tested for the preparation of high water retention hydrogels with good mechanical properties regarding processability and end use applications. Kappa-carrageenan hydrogels have been synthesized by copolymerization with N-vinyl formamide ${ }^{[22]}$ and polyacrylamides ${ }^{[23]}$, which although have shown to have good hydration capacity are not biodegradable. Additionally, hydrogels containing polyacrylamides, when added to the soil, could cause environmental damage due to the accumulation of nitrogen ${ }^{[24]}$.

To continue exploring the possibilities of this natural polymer in the construction of fertilizers with a lower environmental impact and promoting the development of products based on raw materials available in the Colombian Caribbean, we have designed a carrageenan based hydrogel $(\mathrm{CBH})$ less complex in structure and chemical composition in order to encapsulate fertilizer granules ${ }^{[25]}$. This hydrogel 
is porous, semipermeable, biodegradable, nontoxic ${ }^{[26-27]}$, able to absorb up to ten thousand times its weight in water without dissolving or losing its integrity, and its raw material, carrageenan, can be easily obtained ${ }^{[28]}$. Its chemical structure is composed of alternative units of D-galactose and 3,6-anhydrogalactose (3,6 AG) that are bound through $\alpha-1,3$ and $\beta-1,4$ glycosidic bonds. It is an anionic polymer, with high molecular weight. The presence of a cross-linking agent allows carrageenan to form hydrogels in which polysaccharides form three-dimensional networks that swell in water ${ }^{[29,30]}$. The wetting and swelling behavior of the hydrophilic polymers allow the hydrogels to control water penetration, and thus the rate of nutrient dissolution present in the core of the coated fertilizer ${ }^{[31-33]}$. As these nutrients dissolve, they migrate from their initial position in the polymer system to the outer surface of the polymer and are subsequently released into the environment. Laboratory soil column experiments have shown that fertilizer granules encapsulated with the $\mathrm{CBH}$ release nutrients more slowly in comparison to the non-encapsulated fertilizer ${ }^{[25]}$. Although, $\mathrm{CBH}$ proves to be useful in delaying the release of nutrients to the environment, nothing is yet known about its soil release mechanism.

Therefore, the objective of this work is to evaluate the release behavior of fertilizer granules encapsulated within the $\mathrm{CBH}$ by interpreting its $\mathrm{N}$ and $\mathrm{P}$ release profile with various mathematical models in order to obtain insight into its release mechanism accompanied by swelling. These mathematical models let us associate the properties of the materials used to build a CRF and its release mechanism, which makes it possible to improve its design. The mathematical models chosen for this study include the mechanisms of penetration of water within the CFR, diffusion ${ }^{[31-33]}$ and erosion ${ }^{[34]}$. These are important for the CRF design based on the fact that these mechanisms can be controlled through the design of the hydrogel in order to get the greatest release of nutrients to the soil solution when crop plants begin their greatest peak of nutrients absorption.

Considering that the $\mathrm{CBH}$ has been designed to be used in yellow potato crops (Solanum pureja) which are frequently located in soils whose soil $\mathrm{pH}$ vary 4.5 and $6.0^{[35-37]}$, and since the stability of the three-dimensional structure of the hydrogel depends on the $\mathrm{pH}$, the nutrient release in the potato crop could be produced by the breakdown of the gel in an environment with acidic $\mathrm{pH}^{[38]}$. Therefore, the effect of an acidic $\mathrm{pH}$ (4.5) and a $\mathrm{pH}$ close to neutrality (6.3) will be evaluated as release controlling factors. This study will provide relevant information for the future development and field use of a CRF with a carrageenan-based hydrogel as a coating material in yellow potato crops.

\section{Materials and Methods}

\subsection{Synthesis of CBH and preparation of the coated fertilizer}

An aqueous $\kappa$-carrageenan powder solution was prepared by dissolving a commercial food grade $\kappa$-carrageenan powder (Cimpa MCH 5722) in distilled water to obtain a final concentration of $3 \%(\mathrm{w} / \mathrm{v})$. Next, $1.5 \mathrm{~mL}$ of glycerol (Chemi Laboratory) was added as a plasticizing agent, and the mixture was stirred continuously until a clear solution was obtained. This mixture was poured into silicone molds and allowed to cool slowly. Before gelation was completed, NPK fertilizer granules (13-26-6 Nutrimon) were added to the silicone mold at a final concentration of $14 \%(\mathrm{p} / \mathrm{p})$ in order to obtain cylindrical capsules of $1.5 \mathrm{~cm}^{3}$, which were used to analyze the kinetic release behavior through the $\mathrm{CBH}$.

\subsection{Water swelling capacity of the $\mathrm{CBH}$}

$\mathrm{CBH}$ capsules (25) were immersed in $140 \mathrm{ml}$ of $\mathrm{DH}_{2} \mathrm{O}$ for $1,2,4,24 \mathrm{~h}$ and 30 days at $25^{\circ} \mathrm{C}$. At each time, five capsules were taken out of the solution and the equilibrium water content (EWC) was calculated with Equation 1:

$$
\% \mathrm{EWC}=\frac{\mathrm{Wh}-\mathrm{Wd}}{\mathrm{Wd}} * 100
$$

Where Wh is the hydrated weight of the sample and Wd is the dry weight of the sample. An average value was obtained from five parallel measurements. The obtained values were used to calculate the nutrient concentration in the aqueous solution that was released from the $\mathrm{CBH}$ encapsulated fertilizer with Equation 2:

$$
\text { ICS }=\frac{\text { ion in the aqueous phase }(\mathrm{mg})}{\text { Vo- } \mathrm{dWh}_{\mathrm{t}}}
$$

Where Vo is the initial volumen of the aqueous phase and Veq is the Volume of the aqueous phase at the hydrogel absorption equilibrium at time $\mathrm{t}$. Veqt $=\mathrm{Vo}-\mathrm{dWh}$, where d is the water density at $20^{\circ} \mathrm{C}$ and $\mathrm{Wh}$.

\subsection{Release of $\mathrm{NO}_{3}{ }^{-} \mathrm{NH}_{4}{ }^{+}$and $\mathrm{PO}_{4}^{3-}$ from a granulated fertilizer encapsulated with $\mathrm{CBH}$}

The relationship between time and the ammonium $\left(\mathrm{NH}_{4}^{+}\right)$, nitrate $\left(\mathrm{NO}_{3}^{-}\right)$, and phosphate $\left(\mathrm{PO}_{4}^{3-}\right)$ ion release, was determined by placing one capsule of coated NPK fertilizer (13-26-6 Nutrimon) in a stainless-steel basket support inside a $150 \mathrm{~mL}$ beaker with $140 \mathrm{~mL} \mathrm{dH}_{2} \mathrm{O}$ (pH 5.5). The beaker was covered with parafilm and incubated at $25^{\circ} \mathrm{C}$ in a rotatory shaker. Nutrient release was measured at regular sampling times up to $40320 \mathrm{~min}$. At each sampling time, nutrients were measured in the aqueous solution of three replicates.

Samples were analyzed for $\mathrm{NH}_{4}^{+}, \mathrm{NO}_{3}-$ and $\mathrm{PO}_{4}^{-3}$ by the Indophenol blue ${ }^{[39]}$, sodium salicylate ${ }^{[40]}$, and Canterbury colorimetric methods ${ }^{[4]]}$, respectively, using a Thermo Scientific UV-Visible Analyzer EV-300. The concentrations of the ions in the solutions were measured at wavelengths of $640 \mathrm{~nm}$ for $\mathrm{NH}_{4}^{+}, 415$ for $\mathrm{NO}_{3}^{-} \mathrm{nm}$ and $650 \mathrm{~nm}$ for $\mathrm{PO}_{4}^{-3}$. The calibration curves for all the evaluated ions were linear in the tested ranges, going from 0.05 to $5.5 \mathrm{mmol} \mathrm{L}^{-1}$ for $\mathrm{NH}_{4}^{+}$, from 0.0008 to $0.037 \mathrm{mmol} \mathrm{L}^{-1}$ for $\mathrm{NO}_{3}^{-}$and from 0.0005 to $0.024 \mathrm{mmol} \mathrm{L}^{-1}$ for $\mathrm{PO}_{4}^{-3}$, and they had correlation coefficients $\left(\mathrm{R}^{2}\right)$ better than 0.997 . The equations for the regression lines were $y=0.787 x+0.0349$ for $\mathrm{NH}_{4}^{+}$, $y=0.3114 x+0.0015$ for $\mathrm{NO}_{3}^{-}$and $y=0.0189 x+0.0132$ for $\mathrm{PO}_{4}^{-3}$, where $y$ is the absorbance and $x$ is the concentration of the ion.

The same procedure described above was carried out with shorter incubation times up to 240 and $300 \mathrm{~min}$, in order to evaluate the effect that $\mathrm{pH}$ has on the release of the $\mathrm{NH}_{4}^{+}$, $\mathrm{NO}_{3}{ }^{-}$and $\mathrm{PO}_{4}{ }^{3-}$ ions. Besides using $\mathrm{dH}_{2} \mathrm{O}$ with a $\mathrm{pH}$ of 5.5, solutions of pH 4.5 and 6.3 , prepared with acetate buffer and citrate buffer were also used in the release experiments ${ }^{[2,43]}$. 
All the reagents used for preparation of the buffer solutions were provided by Sigma-Aldrich. Phosphate buffer $\mathrm{pH} 6.3$ was prepared with $\mathrm{NaH}_{2} \mathrm{PO}_{4}$ and $\mathrm{Na}_{2} \mathrm{HPO}_{4}$ solutions; therefore, $\mathrm{PO}_{4}^{3-}$ concentration was not measured at $\mathrm{pH} 6.3$

The percentage of released nutrient $(\% \mathrm{RN})$ was calculated by Equation 3:

$$
\% \mathrm{RN}=\frac{\mathrm{Rt}}{\mathrm{Co}} * 100
$$

where Rt is the nutrient concentration in the solution at time $\mathrm{t}$ and $\mathrm{Co}$ is the initial concentration of nutrients in the encapsulate fertilizer.

Nutrient release results from solutions at different $\mathrm{pH}$ values were compared by means of a one-way analysis of variance (ANOVA) using the Statgraphics Centurion XVII program (Version 17.0.16, Statpoint 2009).

\subsection{Evaluation of nutrient release data on mathematical models}

The physical mechanism of nutrient release was determined by comparing the release data with the following five mathematical models. The first is a zero-order model ${ }^{[43]}$, which describes a system where the nutrient release rate is independent of its concentration. To compare the experimental results to this model, the nutrient release data are plotted $v s$. time. The second is a first-order model ${ }^{[44]}$, where the nutrient release is directly proportional to the concentration of the nutrient in the fertilizer. To compare the experimental results to this model, the log of cumulative percentage of nutrient remaining data is plotted vs. time. The third is the Higuchi model ${ }^{[44]}$, where the prime mechanism of nutrient release is diffusion. To compare the experimental results to this model the data obtained in the incubation experiments is plotted as cumulative percentage of the nutrient released vs. the square root of time. The fourth model is the Hixon-Crowell model ${ }^{[44]}$, which describes the nutrient release from systems where there is a change in surface area and diameter of particles and tablets. To compare the experimental results to this model, a graph is plotted between the cube root of nutrient percentage remaining in the fertilizer vs. time. The final model is the Korsmeyer-Peppas mode ${ }^{[44-46]}$, which allows us to identify the type of diffusion of the nutrients incorporated in polymeric matrices with spherical, cylindrical or tablet shapes. In order to compare the experimental results to this model a graph is plotted between log cumulative percentage of nutrient release $v s$. log time. Model equations are presented in Table 1. The model fitting analysis was applied to the data from the incubation experiments at $\mathrm{pH} 4.5,5.5\left(\mathrm{dH}_{2} \mathrm{O}\right)$ and 6.3. To assess the fit of each model to the data, the correlation coefficient was determined for each case. The best model to explain the nutrient release mechanism from $\mathrm{CBH}$, was the one with the highest adjusted correlation coefficient. Data analysis was carried out with the Statgraphics Centurion XVII program (Version 17.0.16, Statpoint 2009).

\section{Results and Discussions}

\subsection{Water swelling capacity of the CBH}

The $\mathrm{CBH}$ absorbs water quickly during the first $8 \mathrm{~h}$ and then, the value remains constant (Figure 1). The absorption of water by the gel is approximately $4 \mathrm{~g}$ in the last 2700 minutes, which allows the calculation of nutrient release taking into account the swelling effect. Another important observation is that the gel manages to absorb 320 times its weight in water and maintain it during the 28 days of the test. During this time and at room temperature, no fungal contamination or deterioration of the hydropolymer matrix was observed.

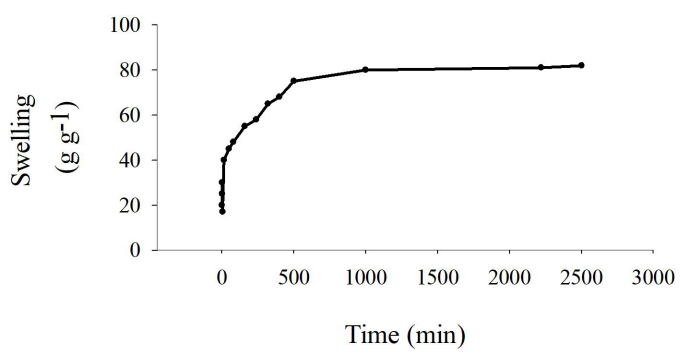

Figure 1. Sewelling behavior of the $\mathrm{CBH}$ hydrogel.

Table 1. Coefficients obtained to evaluate the kinetic model that best fit the experimental nutrient release data.

\begin{tabular}{|c|c|c|c|c|c|c|c|c|c|c|c|c|}
\hline \multirow{4}{*}{ Nutrient } & \multirow{4}{*}{ pH } & \multicolumn{11}{|c|}{ Kinetic Models } \\
\hline & & \multicolumn{2}{|c|}{ Zero Order } & \multicolumn{2}{|c|}{ First Order } & \multicolumn{2}{|c|}{ Higuchi } & \multicolumn{2}{|c|}{ Hixson } & \multicolumn{3}{|c|}{ Korsmeyer-Peppas } \\
\hline & & \multicolumn{2}{|c|}{$Q_{t}=Q_{0}+K_{0} t$} & \multicolumn{2}{|c|}{$\ln Q=\ln Q_{0}+K_{1} t$} & \multicolumn{2}{|c|}{$\mathbf{Q}_{\mathbf{t}}=\mathbf{K}_{\mathbf{H}} \sqrt{ } \mathbf{t}$} & \multicolumn{2}{|c|}{$Q_{0}^{1 / 3}-Q_{t}^{1 / 3}=K_{s} t$} & \multicolumn{3}{|c|}{$Q_{t} / Q_{\infty}=K_{k} t^{n}$} \\
\hline & & $\mathbf{K}$ & $\mathbf{R}^{2}$ & $\mathbf{K}$ & $\mathbf{R}^{2}$ & $\mathbf{K}$ & $\mathbf{R}^{2}$ & $\mathbf{K}$ & $\mathbf{R}^{2}$ & $\mathbf{n}$ & $\mathbf{K}$ & $\mathbf{R}^{2}$ \\
\hline \multirow[t]{3}{*}{$\mathrm{NO}_{3}^{-}$} & 4.5 & 8.99 & 0.95 & 0.93 & 0.53 & 5.09 & 0.97 & 0.19 & 0.55 & 0.61 & 0.35 & 0.99 \\
\hline & 5.5 & 7.70 & 0.71 & 0.84 & 0.44 & 3.32 & 0.91 & 0.12 & 0.74 & 0.44 & 0.65 & 0.95 \\
\hline & 6.3 & 18.11 & 0.58 & 1.02 & 0.84 & 9.55 & 0.77 & 0.32 & 0.63 & 0.54 & 0.38 & 0.92 \\
\hline \multirow[t]{3}{*}{$\mathrm{NH}_{4}^{+}$} & 4.5 & 5.95 & 0.92 & 0.75 & 0.61 & 6.00 & 0.96 & 0.15 & 0.49 & 0.64 & 0.11 & 0.98 \\
\hline & 5.5 & 4.93 & 0.95 & 0.70 & 0.73 & 2.51 & 0.95 & 0.07 & 0.94 & 0.55 & 0.33 & 0.99 \\
\hline & 6.3 & 11.21 & 0.82 & 0.84 & 0.52 & 1.07 & 0.96 & 0.18 & 0.87 & 0.62 & 0.21 & 0.98 \\
\hline \multirow[t]{2}{*}{$\mathrm{PO}_{4}^{-3}$} & 4.5 & 2.00 & 0.92 & 0.71 & 0.77 & 11.18 & 0.86 & 0.01 & 0.94 & 0.56 & 0.31 & 0.82 \\
\hline & 5.5 & 6.38 & 0.73 & 0.26 & 0.38 & 0.97 & 0.94 & 0.10 & 0.78 & 0.67 & 0.40 & 0.97 \\
\hline
\end{tabular}

$\mathrm{K}=$ Release constant, $\mathrm{R}^{2}=$ Adjusted Correlation coefficient, $\mathrm{n}=$ Indicator of nutrient release mechanism from cylindrical shapes. Kinetic Models Parameters: $\mathrm{Q}_{\mathrm{t}}=$ amount of nutrient released at time $\mathrm{t}, \mathrm{Q}_{0}=$ initial concentration of the nutrient at $\mathrm{t}=0$, $\mathrm{K}_{\mathrm{o}}=$ zero order rate constant, $\mathrm{Q}=$ percent of nutrient remaining at time $\mathrm{t}, \mathrm{K}_{1}=$ first order rate constant, $\mathrm{K}_{\mathrm{H}}=$ Higuchi dissolution constant, Ks $=$ Hixson release constant, $\mathrm{K}_{\mathrm{k}}=\mathrm{Korsmeyer}$ release constant. 
During the swelling process, there were no major changes in the cylindrical shape of the capsules.

\subsection{Release mechanism}

The results of the released nutrients as a function of time were adjusted to the different kinetic models, and as expected, according to the correlation coefficient obtained for each nutrient and $\mathrm{pH}$ condition (Table 1), the best fit to the data is presented by the Korsmeyer-Peppas model, confirming diffusion, and not the fracture mechanism, as the mechanism of nutrient release from the $\mathrm{CBH}$ encapsulated fertilizer, even at acidic $\mathrm{pH}$.

Therefore, the Korsmeyer-Peppas model was used to elucidate the type of diffusion from the encapsulated fertilizer. This model describes the nutrient release from a polymeric system with cylindrical shapes, as represented by Equation $4^{[39-40]}$,

$$
\frac{\mathrm{Mt}}{\mathrm{M} \infty}=\mathrm{Kt}^{\mathrm{n}}
$$

where $\mathrm{Mt} / \mathrm{M}_{\infty}$ is the fraction of nutrient released at time $\mathrm{t}$; $\mathrm{K}$ is the release constant, which includes characteristics of the polymer matrix; and $\mathrm{n}$ is the diffusion exponent or nutrient release exponent, an indicator of the nutrient transport mechanism through the polymer. The value of $\mathrm{n}^{[38]}$ characterizes the release mechanism of the nutrients as described in Table 2 in cylindrical shapes.

The graphs of the fraction of nutrients released over time and Equation 5 were used to determine the diffusion coefficient (n) and the release constant (K)

$$
\log \left(\frac{\mathrm{Mt}}{\mathrm{M} \infty}\right)=\log (\mathrm{K})+\mathrm{n} \log (\mathrm{t})
$$

Table 1 shows that the values of $\mathrm{n}$ are between the range of 0.45 to 0.67 , therefore the nutrients follow a diffusion release of the anomalous type, which means that the nutrient release from the CRF coated with $\mathrm{CBH}$ takes place by non-Fickian diffusion ${ }^{[47]}$. This anomalous diffusion occurs when the relaxation time of the polymer's chains is of the same order as the diffusion time of the penetrant solution. Non-Fickian diffusion is also the result of hydropolymer matrix erosion, which is due to chain disentanglement that occurs in physically crosslinked matrices induced by the matrix swelling fluid, and the hydrodynamic conditions imposed in the release environment ${ }^{[47]}$. As the diffusing penetrant enters the polymer, it causes a deformation, which induces a stress driven diffusion. What causes Fick's law to not represent the diffusion in the $\mathrm{CBH}$ polymeric matrix is that it does not take into consideration the viscoelastic nature of polymers ${ }^{[48-50]}$.

\subsection{Rate and percentage of release}

Figures $2 \mathrm{a}, \mathrm{b}, \mathrm{c}$ show the release of nutrients in $\mathrm{dH}_{2} \mathrm{O}$ $(\mathrm{pH} 5.5)$ in a long-term incubation. It is observed that $17 \%$ of $\mathrm{NH}_{4}^{+}$was released after a one-hour incubation and 95\% was released after 28 days. For nitrate, $23 \%$ was released in 24 hours and $68 \%$ in 28 days. In the case of $\mathrm{PO}_{4}^{3-}, 1.8 \%$ of this ion was released in the first ten minutes of incubation and $62 \%$ by day 28 . These in vitro results show that the prototype of a CRF coated with the $\mathrm{CBH}$ does not meet quite well the criteria as a CRF in regard to the European Standardization Committee (CEN), according to which, nutrients released from a CRF in 24 hours must exceed 15\% but not more than $75 \%$ in 28 days ${ }^{[1,52]}$. In spite of this, these study results do not mean that the $\mathrm{CBH}$ cannot be used as a CRF coating material. The in vitro release results are an input that contribute to the tailoring of material for optimal controlled release based on the structure-function relationship of the CRF's building materials. Our experimental data indicate that a significant percentage of the nutrients are being released before 30 days, which means that the structure of the hydrogel must be modified in order to retain the nutrients for a longer time. With a slower nutrient release, it will be more feasible to synchronize the CRF's nutrient release and the crop's onset of the nutrients uptake. In particular, this study is interested in the development of a CRF for potato crops, given the worldwide importance of this crop, with close to 19.3 million hectares planted ${ }^{[53]}$, and more than

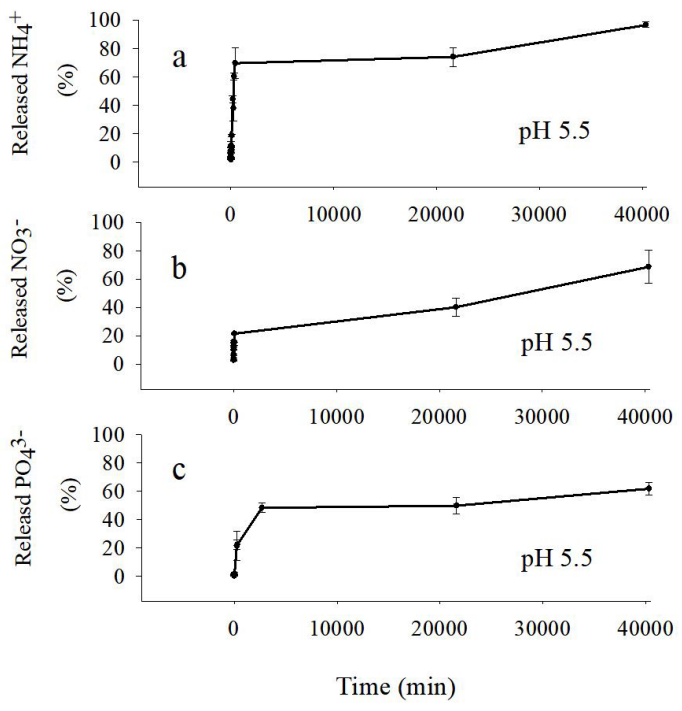

Figure 2. Release behavior of (a) $\mathrm{NH}_{4}^{+}$, (b) $\mathrm{NO}_{3}^{-}$, and (c) $\mathrm{PO}_{4}{ }^{3-}$ in a long term incubation in $\mathrm{dH}_{2} \mathrm{O}, \mathrm{pH}=5.5$.

Table 2. Different release mechanisms for swelling polymeric matrices with cylindrical shape.

\begin{tabular}{ccc}
\hline Release exponent (n) & Nutrient transport mechanism & Rates as a function of time \\
\hline 0.45 & Fickian diffusion & $\mathrm{t}^{-0.5}$ \\
$>0.45-0.89$ & Non Fickian transport & $\mathrm{t}^{\mathrm{n}-1}$ \\
0.89 & Case II transport & Zero order release \\
$>0.89$ & Super case II transport & $\mathrm{t}^{\mathrm{n}-1}$ \\
\hline
\end{tabular}

Source Gouda et al..$^{[4]]}$ 
246.000 tons of NPK fertilizers used in this crop annually in Latin America, in addition to potato being one of the crops with the highest fertilizer application rates around the world $^{[54]}$. The greatest assimilation time for the potato plant is 35 - 45 days after being sown ${ }^{[55]}$. It means that in order to use the CRF coated with $\mathrm{CBH}$ in the potato crop, it would be necessary to modify the coating material to ensure the greatest outflow of nutrients between 35 and 45 days after planting. To diminish the $\mathrm{CBH}$ nutrient release during the first 30 days, the polymer synthesis ratios could be modified to ensure noncovalent spatial networks with three-dimensional conformations that slow down the diffusion of nutrients to the medium. These modifications require the integration of more inner charges to the non covalent spatial networks by cross-linking through covalent chemical bonds, which stabilizes the hydrogel and improves the nutrients retention properties. To integrate more inner charges it is suggested to increase the concentration of any of the following: calcium salts (from 2 to $5 \% \mathrm{w} / \mathrm{v}$ ), glycerol (from 5 to $10 \% \mathrm{w} / \mathrm{v}$ ) or self-assembling peptides ${ }^{[56]}$. Additionally, the hydrogel synthesis $\mathrm{pH}$ could be modified to guarantee the reduction of hydrolysis and thus ensure the formation of stronger networks. On the other hand, the concentration of fertilizer in the capsule could be reduced to produce a longer nutrient diffusion process. The diffusivity could also be adjusted by changing the concentration of plasticizer additives (or solvents) that increase the mobility of the polymer chains in order to reduce the ions mobility, or by adding fillers such as chitosan or starch. The ultimate refinement of the CRF requires field tests, because the CRF performance will depend on many controlled release factors associated with soil type and rainfall precipitation.

\subsection{Effect of solution $\mathrm{pH}$}

The release curves of $\mathrm{NH}_{4}^{+}$and $\mathrm{NO}_{3}^{-}$in solutions with different $\mathrm{pH}$ values are presented in Figures $3 \mathrm{a}$ and $\mathrm{b}$. In this case, no significant differences were observed between $\mathrm{pH}$

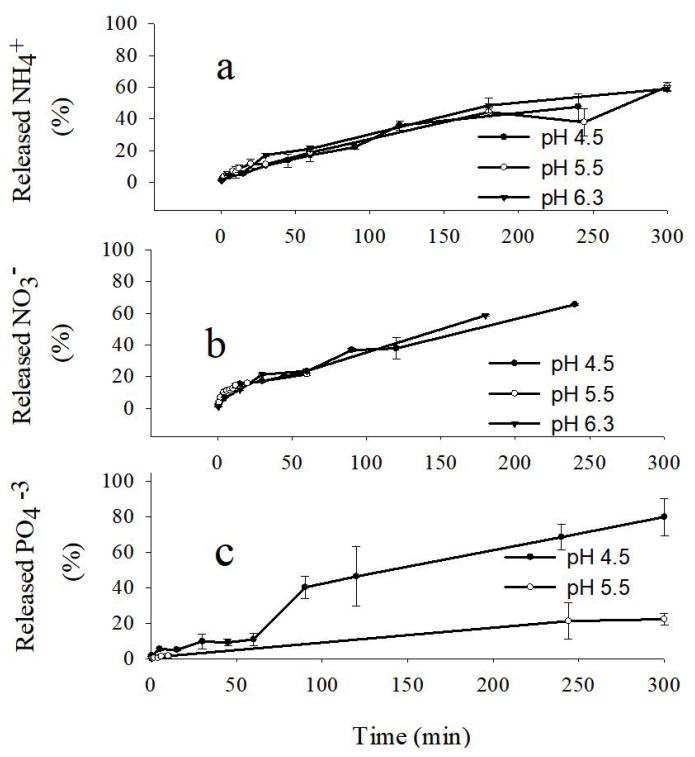

Figure 3. Effect of different $\mathrm{pH}$ values on the (a) $\mathrm{NH}_{4}^{+}$, (b) $\mathrm{NO}_{3}^{-}$, and (c) $\mathrm{PO}_{4}^{3-}$ release behavior. treatments for the $\mathrm{N}$ release from the encapsulated fertilizer to the aqueous medium $(\mathrm{P}>0.05)$. The release curves of $\mathrm{PO}_{4}^{3-}$ in aqueous solution with $\mathrm{pH}$ values of 4.5 and 5.5 are presented in Figure 3 c. The release of $\mathrm{PO}_{4}^{3-}$ towards the aqueous medium is greater at $\mathrm{pH} 4.5(\mathrm{P}<0.05)$. After 300 minutes of starting the experiment, $80 \%$ of $\mathrm{PO}_{4}^{3-}$ in the fertilizer coated with $\mathrm{CBH}$, had already been released. In contrast, at $\mathrm{pH} 5.5$, after 300 minutes of incubation, only $22 \%$ of the ion had been released into the solution. This difference can be explained because aqueous solutions with low $\mathrm{pH}$ values have a higher positive charge of ions in the medium, which attracts the negatively charged phosphate ions found in the hydrogel matrix, which has a negative charge due to the sulfate and hydroxyl groups present in carrageenan.

\section{Conclusions}

A CRF encapsulated with $\kappa$-carrageenan hydrogel plasticized with glycerol was synthesized. It does not fracture at acidic $\mathrm{pH}$ and is able to reduce the speed at which the $\mathrm{NO}_{3}^{-}, \mathrm{PO}_{4}^{3-}$ and $\mathrm{NH}_{4}^{+}$ions of the fertilizer migrate into the medium. The hydrogel has excellent water retention. The Korsmeyer-Peppas model was applied successfully, and it was determined that the ions leave the polymeric matrix by Non-Fickian diffusion without polymer fracture. The results of this study suggest that the fertilizer encapsulated with $\mathrm{CBH}$ may have potential as a CRF in order to reduce the environmental impact imposed by the excessive use of fertilizers, without problems of toxicity or biodegradability.

\section{Acknowledgements}

This work was carried out with the support of the Departamento Administrativo de Ciencia y Tecnología de la República de Colombia (COLCIENCIAS, Grant No. 1202-669-45888) and Universidad Jorge Tadeo Lozano.

\section{References}

1. Russel, D. A., \& Williams, G. G. (1977). History of chemical fertilizer development. Soil Science Society of America Journal, 4l(2), 260-265. http://dx.doi.org/10.2136/sssaj1977.0361599 5004100020020x.

2. Food and Agriculture Organization - FAO. (1981). Crop production levels and fertilizer use (FAO Fertilizer and Plant Nutrition Bulletin; no. 2). Rome: FAO.

3. Tilman, D., Cassman, K. G., Matson, P. A., Naylor, R., \& Polasky, S. (2002). Agricultural sustainability and intensive production practices. Nature, 418(6898), 671-677. http://dx.doi. org/10.1038/nature01014. PMid:12167873.

4. Cassman, K. G., Dobermann, A., \& Walters, D. T. (2002). Agroecosystems, nitrogen-use efficiency, and nitrogen management. Ambio, 31(2), 132-140. http://dx.doi.org/10.1579/0044-744731.2.132. PMid:12078002.

5. Smil, V. (2000). Phosphorus in the environment: natural flows and human interferences. Annual Review of Energy and the Environment, 25(1), 53-88. http://dx.doi.org/10.1146/annurev. energy.25.1.53.

6. Bouwman, A. F., Boumans, L. J. M., \& Batjes, N. H. (2002). Emissions of $\mathrm{N}_{2} \mathrm{O}$ and $\mathrm{NO}$ from fertilized fields: summary of available measurement data. Global Biogeochemical Cycles, 16(4), 6-13. http://dx.doi.org/10.1029/2001GB001811. 
7. Zhao, B. Q;, Li, X. Y., Liu, H., Wang, B. R., Zhu, P., Huang, S. M., Bao, D. J., Li, Y. T., \& So, H. B. (2011). Results from longterm fertilizer experiments in China: the risk of groundwater pollution by nitrate. NJAS Wageningen Journal fo Life Siences, 58, 177-183.

8. Ongley, O. D. (1996). Control of water pollution from agriculture (FAO Irrigation and Drainage; Paper No. 55) Rome: Food and Agriculture Organization of the United Nations.

9. Bhatia, A., Pathak, H., \& Aggarwal, P. K. (2004). Inventory of methane and nitrous oxide emissions from agricultural soils of India and their global warming potential. Current Science, 87(3), 317-324.

10. Withers, P. J. A., Neal, C., Jarvie, H. P., \& Doody, D. G. (2014). Agriculture and eutrophication: where do we go from here? Sustainability, 6(9), 5853-5875. http://dx.doi.org/10.3390/ su6095853.

11. Molina-Herrera, S., Haas, E., Klatt, S., Kraus, D., Augustin, J., Magliulo, V., Tallec, T., Ceschia, E., Ammann, C., Loubet, B., Skiba, U., Jones, S., Brümmer, C., Butterbach-Bahl, K., \& Kiese, R. (2016). Modeling study on mitigation of $\mathrm{N}_{2} \mathrm{O}$ emissions and $\mathrm{NO}_{3}$ leaching at different agricultural sites across Europe using Landscape DNDC. The Science of the Total Environment, 553, 128-140. http://dx.doi.org/10.1016/j. scitotenv.2015.12.099. PMid:26909705.

12. Naz, M. Y., \& Sulaiman, A. S. (2016). Slow release coating remedy for nitrogen loss from conventional urea: a review. Journal of Controlled Release, 225, 109-120. http://dx.doi. org/10.1016/j.jconrel.2016.01.037. PMid:26809006.

13. Cong, Z., Yazhen, S., Changwen, D., Jianmin, Z., Huoyan, W., \& Xiaoqin, C. (2010). Evaluation of waterborne coating for controlled release fertilizer using wursterfluidized bed. Industrial \& Engineering Chemistry Research, 49(20), 96449647. http://dx.doi.org/10.1021/ie101239m.

14. Azeem, B., KuShaari, K., Man, Z. B., Basit, A., \& Thanh, T. H. (2014). Review on materials and methods to produce controlled release coated urea fertilizer. Journal of Controlled Release, 181, 11-21. http://dx.doi.org/10.1016/j.jconrel.2014.02.020. PMid:24593892.

15. Ali, S., \& Danafar, F. (2015). Controlled-release fertilizers: advances and challenges. Life Science Journal, 12(11), 33-45.

16. Guilherme, M. R., Aouada, F. A., Fajardo, A. R., Martins, A. F., Paulino, A. T., Davi, M. F., Rubira, A. F., \& Muniz, E. C. (2015). Superabsorbent hydrogels based on polysaccharides for application in agriculture as soil conditioner and nutrient carrier: a review. European Polymer Journal, 72, 365-385. http://dx.doi.org/10.1016/j.eurpolymj.2015.04.017.

17. Shaviv, A., \& Mikkelsen, R. L. (1993). Controlled-release fertilizers to increase efficiency of nutrient use and minimize environmental degradation: a review. Nutrient Cycling in Agroecosystems, 35(1-2), 1-22.

18. Yang, X., Geng, J., Li, C., Zhang, M., \& Tian, X. (2016). Cumulative release characteristics of controlled-release nitrogen and potassium fertilizers and their effects on soil fertility, and cotton growth. Scientific Reports, 6(1), 39030. http://dx.doi. org/10.1038/srep39030. PMid:27966638.

19. Chen, J., Lu, S., Zhang, Z., Zhao, X., Li, X., Ning, P., \& Liu, M. (2018). Environmentally friendly fertilizers: a review of materials used and their effects on the environment. The Science of the Total Environment, 613-614, 829-839. http:// dx.doi.org/10.1016/j.scitotenv.2017.09.186. PMid:28942316.

20. Campos, E. V. R., Oliveira, J. L., Fraceto, L. F., \& Singh, B. (2015). Polysaccharides as safer release systems for agrochemicals. Agronomy for Sustainable Development, 35(1), 47-66. http://dx.doi.org/10.1007/s13593-014-0263-0.

21. Wang, J., Liu, S., Qin, Y., Chen, X., Xing, R., Yu, H., Li, K., $\&$ Li, P. (2017). Preparation and characterization of controlled release fertilizers coated with marine polysaccharide derivatives. Chinese Journal of Oceanology and Limnology, 35(5), 10861093. http://dx.doi.org/10.1007/s00343-017-6074-9.

22. Mishra, M. M., Yadav, M., Sand, A., Tripathy, J., \& Behari, K. (2010). Water soluble graft copolymer ( $\kappa$-carrageenang-N-vinyl formamide): Preparation, characterization and application. Carbohydrate Polymers, 80(1), 235-241. http:// dx.doi.org/10.1016/j.carbpol.2009.11.009.

23. Nakhjiri, M. T., Marandi, G. B., \& Kurdtabar, M. (2018). Poly(AAco-VPA) hydrogel cross-linked with N-maleyl chitosan as dye adsorbent: Isotherms, kinetics and thermodynamic investigation. International Journal of Biological Macromolecules, 117, 152-166. http://dx.doi.org/10.1016/j.ijbiomac.2018.05.140. PMid:29802921.

24. Pettinelli, N., Rodríguez-Llamazares, S., Abella, V., Barral, L., Bouza, R., Farrag, Y., \& Lago, F. (2019). Entrapment of chitosan, pectin or $\kappa$-carrageenan within methacrylate based hydrogels: effect on swelling and mechanical properties. Materials Science and Engineering C, 96, 583-590. http:// dx.doi.org/10.1016/j.msec.2018.11.071. PMid:30606569.

25. Santamaría Vanegas, J., Rozo Torres, G., \& Barreto Campos, B. (2019). Characterization of a $\kappa-C a r r a g e e n a n$ Hydrogel and its Evaluation as a Coating Material for Fertilizers. Journal of Polymers and the Environment, 27(4), 774-783. http://dx.doi. org/10.1007/s10924-019-01384-4.

26. Weiner, M. L., Nuber, D., Blakemore, W. R., Harriman, J. F., \& Cohen, S. M. (2007). A 90-day dietary study on kappa carrageenan with emphasis on the gastrointestinal tract. Food and Chemical Toxicology, 45(1), 98-106. http://dx.doi. org/10.1016/j.fct.2006.07.033. PMid:17034924.

27. Weiner, M. L. (2016). Parameters and pitfalls to consider in the conduct of food additive research, Carrageenan as a case study. Food and Chemical Toxicology, 87, 31-44. http://dx.doi. org/10.1016/j.fct.2015.11.014. PMid:26615870.

28. Campo, V. L., Kawano, D. F., Silva, D. B. Jr, \& Carvalho, I. (2009). Carrageenans: biological properties, chemical modifications and structural analysis - A review. Carbohydrate Polymers, 77(2), 167-180. http://dx.doi.org/10.1016/j.carbpol.2009.01.020.

29. Wang, Y., Liu, M., Ni, B., \& Xie, L. (2012). к-Carrageenansodium alginate beads and superabsorbet coated nitrogen fertilizer with slow release, water retention, and anticompaction properties. Industrial \& Engineering Chemistry Research, 51(3), 1413-1422. http://dx.doi.org/10.1021/ie2020526.

30. Rhim, J. W., \& Wang, L. (2013). Mechanical and water barrier properties of agar/ $\kappa$-carrageenan/konjac glucomannan ternary blend biohydrogel films. Carbohydrate Polymers, 96(1), 71-81. http://dx.doi.org/10.1016/j.carbpol.2013.03.083. PMid:23688456.

31. Shavit, U., Shaviv, A., \& Zaslavsky, D. (1995). Solute diffusion coefficient in the internal medium of a new gel based controlled release fertilizer. Journal of Controlled Release, 37(1), 21-32. http://dx.doi.org/10.1016/0168-3659(95)00043-8.

32. Shavit, U., Reiss, M., \& Shaviv, A. (2003). Wetting mechanism of gel based controlled-released fertilizers. Journal of Controlled Release, 88(1), 71-83. http://dx.doi.org/10.1016/ S0168-3659(02)00455-8. PMid:12586505.

33. Sempeho, S. I., Kim, H. T., Mubofu, E., \& Hilonga, A. (2014). Meticoulos overview on the controlled release fertilizers. Advances in Chemistry, 2014(1), 363071.

34. Trenkel, M. E. (1997). Improving fertilizers use efficiency (Controlled-Release and Stabilized Fertilizers in Agriculture). Paris: International Fertilizer Industry Association.

35. Fageria, N. K., \& Nascente, A. S. (2014). Management of soil acidity of south american soils for sustainable crop production. In D. L. Sparks (Ed.), Advances in agronomy (chap. 6, pp. 221-275). Academic Press. 
36. Food and Agriculture Organization - FAO. (2019). Año internacional de la papa 2008. Rome: FAO. Retrieved in 2019, May 23, from http://www.fao.org/potato-2008/es/lapapa/ cultivo.html

37. Marín, J. G. (1985). Fertilidad general de los suelos de cinco zonas paperas de Colombia. Revista ICA, 20(1), 203-209.

38. Rozo, G., \& Rozo, C. (2012). Colombia patent 08043691 : procedure for extracting and purify kappa carrageenan obtained from Hypnea musciformis (Certificate No. 29475; Gazette No. 597). Colombia.

39. Lin, K., Li, P., Wu, Q., Feng, S., Ma, J., \& Yuan, D. (2018). Automated determination of ammonium in natural waters with reverse flow injection analysis based on the indophenol bluemethod with o-phenylphenol. Microchemical Journal, 138, 519-525. http://dx.doi.org/10.1016/j.microc.2018.02.004.

40. Monteiro, M. I. C., Ferreira, F., Oliveira, N. M. M., \& Ávila, A. K. (2003). Simplified version of the sodium salicylate method for analysis of nitrate in drinking waters. Analytica Chimica Acta, 477(1), 125-129. http://dx.doi.org/10.1016/ S0003-2670(02)01395-8.

41. College of Science University of Canterbury Christchurch New Zealand. (2018). Determination of phosphate concentration in soil. Retrieved in 2018, December 19, from: https://www. canterbury.ac.nz/media/documents/science-outreach/phosphate. pdf

42. Green, A. A. (1993). The preparation of acetate and phosphate buffer solutions of known $\mathrm{pH}$ and ionic strength. Journal of the American Chemical Society, 55(6), 2331-2336. http://dx.doi. org/10.1021/ja01333a018.

43. Elving, P. J., Markowitz, J. M., \& Rosenthal, I. (1956). Preparation of buffer systems of constant ionic strength. Analytical Chemistry, 28(7), 1179-1180. http://dx.doi.org/10.1021/ac60115a034.

44. Gouda, R., Baishya, H., \& Qing, Z. (2017). Application of mathematical models in drug release kinetics of Carbidopa and Levodopa ER Tablets. Journal of Developing Drugs, 6(2), $1-8$.

45. Ritger, P. L., \& Peppas, N. A. (1987). A simple equation for description of solute release I. Fickian and non-Fickian release from non-swellable devices in the form of slabs, spheres, cylinders or discs. Journal of Controlled Release, 5(1), 23-36. http://dx.doi.org/10.1016/0168-3659(87)90034-4.
46. Ritger, P. L., \& Peppas, N. A. (1987). A simple equation for description of solute release II. Fickian and anomalous release from swellable devices. Journal of Controlled Release, 5(1), 37-42. http://dx.doi.org/10.1016/0168-3659(87)90035-6.

47. Grassi, M., \& Grassi, G. (2005). Mathematical modelling and controlled drug delivery: matrix systems. Current Drug Delivery, 2(1), 97-116. http://dx.doi.org/10.2174/1567201052772906. PMid:16305412.

48. Thomas, L. N., \& Windle, A. H. (1980). A deformation model for case II diffusion. Polymer, 21(6), 613-619. http://dx.doi. org/10.1016/0032-3861(80)90316-X.

49. Thomas, L. N., \& Windle, A. H. (1981). Diffusion mechanics of the system PMMA-methano. Polymer, 22(5), 627-639. http://dx.doi.org/10.1016/0032-3861(81)90352-9.

50. Thomas, L. N., \& Windle, A. H. (1982). A theory of case II diffusion. Polymer, 23(4), 529-542. http://dx.doi.org/10.1016/00323861(82)90093-3.

51. Trenkel, M. E. (2010). Slow and controlled release and stabilized fertilizers: an option for enhancing nutrient use efficiency in agriculture. Paris: International Fertilizer Industry Association.

52. Shaviv, A. (2001). Advances in controlled release fertilizers. Advances in Agronomy, 71, 1-49. http://dx.doi.org/10.1016/ S0065-2113(01)71011-5.

53. Food and Agriculture Organization of the United Nations FAO. (2019). Retrieved in 2013, March 20, from http://www. fao.org/potato-2008/en/world/

54. Food and Agriculture Organization of the United Nations FAO. (2002). Fertilizer use by crop (FAO Fertilizer and Plant Nutrition Bulletin; no. 16). Rome: FAO.

55. Harmunt, K., \& Stephan-Beckmann, S. (1997). Development, growth and chemical composition of the potato crop (Solanum tuberosum L.). II. Tuber and whole plant. Potato Research, 40(1), 135-153.

56. Echalier, C., Valot, L., Martinez, J., Mehdi, A., \& Subra, G. (2019). Chemical cross-linking methods for cell encapsulation in hydrogels. Materials Today Communications, 100536. http:// dx.doi.org/10.1016/j.mtcomm.2019.05.012.

Received: Apr. 09, 2019

Revised: June 12, 2019

Accepted: June 13, 2019 